\title{
Characterization on Surface of Mercerized and Enzymatic Scoured Cotton after Different Temperature of Drying
}

\author{
Igor Jordanov ${ }^{*}$ and Biljana Mangovska
}

Ss. Cyril \& Methodius University, Faculty of Technology and Metallurgy, R. Boskovic 16, 1000 Skopje, Macedonia

\begin{abstract}
The influence of different temperature of drying after mercerizing on enzymatic scouring through changes in the surface properties and scouring efficiency were investigated. Mercerized cotton yarns dried at room temperature $\left(20^{\circ} \mathrm{C}\right)$ and $80^{\circ} \mathrm{C}$ were scoured with alkaline and acid pectinases. Alkaline scouring was also done for comparing. Surface properties and scouring efficiency were followed through the CIE whiteness degree, CIELAB coordinates, X-ray photoelectron spectroscopy, staining the non-cellulosic components with appropriate dyes, wettability and surface fee energy. Mercerization changes the cotton surface, and removes part of the cuticle components. Drying at $80^{\circ} \mathrm{C}$ melted down the residual waxes covering the surface of the fiber, enhancing the alkaline and alkaline pectinase scouring and enabling acid pectinase scouring. While way of scouring has significant influence on the most measured properties, temperature of drying has significant influence on CIE whiteness, CIELAB coordinates $a^{*}, b^{*}, L^{*}{ }_{B B}$ and on $x$-ray photoelectron spectroscopy value $\mathrm{O} / \mathrm{C}$.
\end{abstract}

Keywords: Cotton, characterization, mercerizing, pectinases, scouring, surface.

\section{INTRODUCTION}

The treatment of cotton yarns includes singing to remove the protruding fibers, mercerization to give better dimensional stability, increased luster, increased dye and finishingchemical uptake, better mechanical properties and smoothness, scouring to remove non-cellulosic impurities and oxidative bleaching to destroy natural coloring matter for white program or dyeing [1].

Yarn mercerization is usually done on raw or scoured yarns. Mercerization that is done before scouring is called dry, while mercerization after scouring is called wet mercerization [2].

The common industrial removal of the non-cellulosic impurities, located mainly in the cuticle and primary layer, is conventionally carried out by treating the yarn with sodium hydroxide solution in the presence of chelating agents and surfactants at a boiling temperature for one to two hours. These working conditions soaponify or emulsify the waxes and fats, turn pectin into soluble sodium pectat, proteins into soluble sodium salts of different amino acids, solubilize the ash and dissolve hemicelluloses with low DP [3]. Scoured cotton has improved wettability, and almost completely removed cuticle and non-cellulosic components.

Several attempts have been made to replace the conventional alkaline with enzymatic scouring that works at milder conditions. Different enzyme classes have been investigated for use in scouring, including cellulases, pectinases, lipases, proteases, and their mixtures. The best results were obtained with pectinases [4-27]. Properly selected non-ionic surfactants and mechanical agitation are very important for

*Address correspondence to this author at the Ss. Cyril \& Methodius University, Faculty of Technology and Metallurgy, R. Boskovic 16, 1000 Skopje, Macedonia; E-mail: jordanov@tmf.ukim.edu.mk sufficient scouring too [5]. In aqueous solution pectinases penetrate the cuticle through cracks or micro-pores digesting the pectin and facilitating partial removal of the cuticle components $[6,12]$.

Cotton fibers are subjected at different temperatures during growing, wet pretreatments, laundering and ironing, which alter their properties. Elevated temperature of drying has altered cotton fiber properties, such as length, strength, elongation and spinning performances [28], as well as surface components and internal porous system [29]. Elevated temperature decreased the cotton pectin content, gin heating decreased moisture regain of cotton fiber as a result of dehydration of cellulose, which led to an irreversible change in cellulose structure and therefore decrease of strength [28, 29]. The temperature of drying after mercerizing has influenced the dye and water uptake of cotton fiber too [2, $30,31]$. Mercerized and directly dyed cotton adsorbs more dye than dried before dyeing [31]. The increase of the temperature of drying decreases the dye uptake and water absorption [2].

In this work, an attempt was made to investigate the influence of different temperature of drying after mercerizing on enzymatic scouring through characterization of the cuticle components and changes in the surface properties.

\section{EXPERIMENTAL}

\subsection{Materials and Methods}

\subsubsection{Materials}

Plied ring-worsted cotton yarn with a linear density of 30x2 tex spun with knitting twists (330 twists per meter) was used in the experiments. BioPrep 3000L (Novozymes), an alkaline pectinase (EC 4.2.2.2) produced by the submerged fermentation of a genetically modified bacillus microorga- 
Table 1. Ingredients and Conditions of Alkaline [21], Alkaline Pectinase [21] and Acid Pectinase Scouring [22]

\begin{tabular}{|c|c|c|c|c|c|c|}
\hline Scouring Procedure & Ingredients & pH at Start & $\mathrm{T}_{1}\left({ }^{\circ} \mathrm{C}\right)$ & $t_{1}(\min )$ & $\mathrm{T}_{2}\left({ }^{\circ} \mathrm{C}\right)$ & $\mathbf{t}_{2}(\mathbf{m i n})$ \\
\hline Alkaline & $\begin{array}{c}3.2 \mathrm{gdm}^{-3} \mathrm{NaOH} \\
1 \mathrm{gdm}^{-3} \text { Kemonecer NI } \\
2 \mathrm{gdm}^{-3} \text { Cotoblanc HTD-N }\end{array}$ & 12 & 100 & 60 & & \\
\hline Alkaline pectinase & $\begin{array}{c}0.15 \mathrm{gdm}^{-3} \mathrm{Na}_{3} \mathrm{PO}_{4} \\
1 \mathrm{gdm}^{-3} \mathrm{Kemonecer} \mathrm{NI} \\
0.666 \mathrm{BioPrep} 3000 \mathrm{~L} \mathrm{gkg}^{-1} \\
0.4 \mathrm{~g} / \mathrm{dm}^{3} \text { EDTA }\end{array}$ & 9 & 55 & 30 & 90 & 15 \\
\hline Acid pectinase & $\begin{array}{c}0.5 \mathrm{gdm}^{-3} \mathrm{CH}_{3} \mathrm{COOH}, 0.5 \mathrm{gdm}^{-3} \mathrm{CH}_{3} \mathrm{COONa} \\
1 \mathrm{gdm}^{-3} \text { Kemonecer NI } \\
0.625 \mathrm{NS} 29048 \mathrm{gkg}^{-1} \\
0.8 \mathrm{gdm}^{-3} \text { EDTA }\end{array}$ & 4 & 45 & 30 & 90 & 15 \\
\hline
\end{tabular}

nism, and NS 29048 (Novozymes), an acid pectinase, were also used in the experiment.

\subsubsection{Methods}

Mercerization was done on Jäegli hank mercerization equipment by rolling the hanks in $23.5 \% \mathrm{NaOH}$ solution and $1 \mathrm{gdm}^{-3}$ Subitol MEZ-N (CHT-Germany), wetting agent at $18^{\circ} \mathrm{C}$. Next, the hanks were extended by application of tension to the original length, rinsed with hot $\left(80^{\circ} \mathrm{C}\right)$ and cold $\left(18^{\circ} \mathrm{C}\right)$ water for $1 \mathrm{~min}$ under tension, neutralized and rinsed.

One part of mercerized cotton yarns in form of hanks was centrifuged and dried at room temperature $\left(20^{\circ} \mathrm{C}\right)$. The other part of the mercerized cotton yarns was centrifuged and dried at $80^{\circ} \mathrm{C}$.

Mercerized cotton yarns in the form of hanks were scoured by alkaline and acid pectinase in an Ahiba Turbomat TM-6 apparatus for laboratory dyeing in the bath with liquor ratio 50:1. Alkaline scouring was also done. All scouring procedures were duplicated. The recipes and treatment conditions are displayed in Table 1. At the end of all enzymatic scouring, EDTA was added in the bath and the temperature was raised to $90^{\circ} \mathrm{C}$ for $15 \mathrm{~min}$ to stop the enzyme activity. After all treatments, the yarns were rinsed at $90^{\circ} \mathrm{C}$ for $10 \mathrm{~min}$, at $70^{\circ} \mathrm{C}$ for $10 \mathrm{~min}$, and several times with cold water to accomplish neutralization.

The sample codes of obtained yarns are given in Table 2 .

\subsection{Testing and Analysis}

The degree of whiteness and CIELAB coordinates, such as lightness $\left(\mathrm{L}^{*}\right), \mathrm{a}^{*}, \mathrm{~b}^{*}$, chroma $\left(\mathrm{C}^{*}\right)$ and hue $\left(\mathrm{H}^{*}\right)$ were measured on a Datacolor Spectraflesh SF 600+ reflection spectrophotometer (D65 light source, observer $10^{\circ}$ ). CIE Whiteness was calculated according to the CIE formula given in EN ISO 105-J02:1999 standard. The results represent an average of five measuring with the coefficient of variation lower than $5 \% . \Delta \mathrm{E}^{*}$ was calculated according to Equation 1.

$$
\Delta E=\left[\left(\Delta L^{*}\right)^{2}+\left(\Delta a^{*}\right)^{2}+\left(\Delta b^{*}\right)^{2}\right]^{\frac{1}{2}}
$$

X-ray photoelectron spectroscopy (XPS) measurements were performed using a VG ESCALAB II electron spectrometer under base pressure of $1 \times 10^{-8} \mathrm{~Pa}$. Two different spots with $0.9 \mathrm{~cm}^{2}$ were analyzed per sample. The samples were irradiated with non-monochromatized $\mathrm{AlK} \alpha$ radiation

Table 2. Codes of the Yarn Samples

\begin{tabular}{|c|c|}
\hline Codes & Samples \\
\hline \hline $\mathrm{R}$ & Raw \\
\hline M20 & Mercerized, dried at $20^{\circ} \mathrm{C}$ \\
\hline M20SA & Mercerized, dried at $20^{\circ} \mathrm{C}$, scoured with $\mathrm{NaOH}$ and again dried at $20^{\circ} \mathrm{C}$ \\
\hline M20SB & Mercerized, dried at $20^{\circ} \mathrm{C}$, scoured with BioPrep $3000 \mathrm{~L}$ and again dried at $20^{\circ} \mathrm{C}$ \\
\hline M20SN & Mercerized, dried at $20^{\circ} \mathrm{C}$, scoured with $\mathrm{NS} 29048$ and again dried at $20^{\circ} \mathrm{C}$ \\
\hline M80 & Mercerized, dried at $80^{\circ} \mathrm{C}$ \\
\hline M80SA & Mercerized, dried at $80^{\circ} \mathrm{C}$, scoured with $\mathrm{NaOH}$ and again dried at $80^{\circ} \mathrm{C}$ \\
\hline M80SB & Mercerized, dried at $80^{\circ} \mathrm{C}$, scoured with BioPrep $3000 \mathrm{~L}$ and again dried at $80^{\circ} \mathrm{C}$ \\
\hline M80SN & Mercerized, dried at $80^{\circ} \mathrm{C}$, scoured with $\mathrm{NS} 29048$ and again dried at $80^{\circ} \mathrm{C}$ \\
\hline
\end{tabular}


$(1486.6 \mathrm{eV})$ with a total instrumental resolution of $\sim 1 \mathrm{eV}$ for the Ag3d5/2 line. The photoelectron spectra were corrected by subtracting a Shirley-type background and were quantified using the peak area and Scofield's photo-ionization cross-sections. Survey spectra were recorded with a pass energy of $20 \mathrm{eV}$ (step size of $0.5 \mathrm{eV}$ ), from which the surface chemical compositions were determined (C1s; O1s). In addition, high-resolution $\mathrm{C} 1 \mathrm{~s}$ spectra were recorded with a pass energy of $20 \mathrm{eV}$ (step size of $0.1 \mathrm{eV}$ ), from which the carbon chemical states were determined. All binding energy values were determined using a background substraction method followed by $\mathrm{C} 1 \mathrm{~s}$ curve deconvolution into four Gaussian's curve. The peak positions of these curves were fixed at $285.0 \mathrm{eV}(\mathrm{C}-\mathrm{C}), 286.6 \mathrm{eV}(\mathrm{C}-\mathrm{O}), 288.1 \mathrm{eV}(\mathrm{O}-\mathrm{C}-\mathrm{O})$, and $289.4(\mathrm{O}-\mathrm{C}=\mathrm{O})$.

To detect the quantity of waxes dyeing in the $0.4 \%$ Oil red (C.I. 26125) was done as described by Akin et al. [32].

To detect the quantity of pectin and protein, dyeing of cotton with cationic and acid dyes was done, respectively [33].

To detect the quantity of pectin, dyeing in a bath with liquor ratio 50:1 with $0.5 \%$ Methylene blue (cationic dye), 1 $\mathrm{gdm}^{-3}$ Kemonecer NI, at $\mathrm{pH} 4.5\left(\mathrm{CH}_{3} \mathrm{COOH}\right)$ at $90^{\circ} \mathrm{C}$ for 30 min was performed in an Ahiba Turbomat TM-6 dyeing apparatus. After dyeing, the cotton yarns were rinsed with water for $10 \mathrm{~min}$ at room temperature.

To detect the quantity of proteins, dyeing in a bath with liquor ratio 50:1 with 0.5\% Bemacid blau GLF 200\% (acid dye), $1 \mathrm{gdm}^{-3}$ Kemonecer NI, $1 \mathrm{gdm}^{-3}\left(\mathrm{NH}_{4}\right)_{2} \mathrm{SO}_{4}$, at $90{ }^{\circ} \mathrm{C}$ for $30 \mathrm{~min}$ was performed in an Ahiba Turbomat TM-6 dyeing apparatus. After dyeing, the cotton yarns were rinsed with water for $10 \mathrm{~min}$ at room temperature and after drying lightness values were measured. The results are an average of five measurements with the coefficient of variation lower than $5 \%$.

Wettability of the yarns was determined by thin-layer wicking experiments. According to theoretical considerations [34], the rate of liquid penetration (wicking) into a porous solid can be described by the general form of the Washburn equation:

$x^{2}=\frac{R \gamma_{L} \cos \theta}{2 \eta} t$

where:

$x$ - the distance penetrated,

$R \quad$ - the apparent (effective) capillary radius of the porous solid,

$t$ - the penetration time for the distance $x$,

$\gamma_{L}$ - the surface tension of the liquid,

$\theta \quad$ - the dynamic contact angle of the liquid which appears at the penetration front,

$\eta \quad-$ the liquid viscosity.

In the thin-layer wicking experiment, the yarn sample was placed in a vertical position. When the contact between the yarn and the wicking liquid was established, the time, $t$, for the distance $x=2 \mathrm{~cm}$ was measured at $20 \pm 1^{\circ} \mathrm{C}$. For each yarn, at least ten wicking measurements were made, from which the average value of $t$ was calculated. Coefficients of variation of calculated $t$ values were lower than $5 \%$. As recommended by van Oss [34], the value of $R$ was determined by Equation 2 from the results of the wicking rate of liquids which were expected to spread spontaneously over the solid. This is the reason why low-energy $n$-heptane (C7) was used, and in this case, $\cos \theta=1$. To fulfill the conditions of the spreading regime, the yarn samples were pre-contacted with saturated C7 vapor for 24 hours. To determine $\theta$ for high-energy non-spreading liquids, (e.g., diiodomethane (DIM), water (W) and formamide (FA), which are assumed to form a dynamic contact angle with the capillary wall during penetration), the wicking experiments were performed on bare yarn samples. In this case, the finite dynamic contact angle, $\theta$ (greater than 0 ) was determined from the wicking results. Considering a geometric mean relationship (Good, Adamson), the dispersion, $\gamma_{s}^{d}$, and polar, $\gamma_{S}^{p}$, components of the solid surface, and the free energy, $\gamma_{s}^{\text {tot }}$, of the yarns were calculated from the following relationships (Owens-Wendt-Kaelbel) [35, 36]:

$(1+\cos \theta) \gamma_{L}=2 \sqrt{\gamma_{S}^{d} \gamma_{L}^{d}}+2 \sqrt{\gamma_{S}^{p} \gamma_{L}^{p}}$

$\gamma_{S}^{t o t}=\gamma_{S}^{d}+\gamma_{S}^{p}$

where $S$ stands for the yarn and $L$ for the wicking liquid. Surface tension components of the liquids used are presented in Table 3.

All investigated parameters were analyzed by main effects analysis of variance (ANOVA) for the different way of scouring (variable A), temperature of drying after mercerizing (variable B) using the STATISTICA 6 program. ANOVA gives information about the influence of variables on the response of the investigated parameters [37], and is based on the Fisher $(\mathrm{F})$ test. Evaluated $\mathrm{F}$ values must be higher than tabulated. The tabulated $F$ test value for a significance level of $\alpha=0.05$, degrees of freedom $v_{1}=2$ and $v_{2}=2$, and way of scouring (variable A) is $F_{A}(2,2)=19.00$. The value for different temperatures of drying after mercerizing (variable B) and for degrees of freedom $v_{1}=1$ and $v_{2}=2$, is $\mathrm{F}_{\mathrm{B}}(1,2)=18.51$.

Coefficients of correlation between investigated parameters were also calculated [37].

Table 3. Values of Surface Tension, $\gamma_{L}$, and its Dispersion, $\gamma_{L}^{d}$, and Polar, $\gamma_{L}^{p}$, Components, for the Studied Liquids and their Viscosity, $\eta$, at $20^{\circ} \mathrm{C}$ [36]

\begin{tabular}{|c|c|c|c|c|c|}
\hline Liquid & $\begin{array}{c}\text { Liquid } \\
\text { Abbreviation }\end{array}$ & $\begin{array}{c}\gamma_{L} \\
\left(\mathbf{m J m}^{-2}\right)\end{array}$ & $\begin{array}{c}\gamma_{L}^{d} \\
\left(\mathbf{m J m}^{-2}\right)\end{array}$ & $\begin{array}{c}\gamma_{L}^{p} \\
\left(\mathbf{m J m}^{-2}\right)\end{array}$ & $\begin{array}{c}\eta \\
(\mathbf{m P a} \mathbf{~ s})\end{array}$ \\
\hline \hline$n$-heptane & C7 & 20.4 & 20.4 & 0 & 0.41 \\
\hline Diiodomethane & DIM & 50.8 & 50.8 & 0 & 2.80 \\
\hline Water & W & 72.8 & 21.8 & 51.0 & 1.00 \\
\hline Formamide & FA & 58.0 & 39.0 & 19.0 & 4.55 \\
\hline
\end{tabular}




\section{RESULTS AND DISCUSSION}

\subsection{CIE Whiteness Degree, CIELAB Coordinates}

The results given in Table $\mathbf{4}$ indicate that CIE whiteness degree of M20 and M80 are $87 \%$ and $80 \%$ higher than the CIE whiteness on raw cotton yarn, respectively. These results indicate that mercerization and the temperature of drying after mercerizing has an influence on the CIE whiteness. Mercerized yarn dried at $20^{\circ} \mathrm{C}$ has $4.13 \%$ higher CIE whiteness than dried at $80^{\circ} \mathrm{C}$. After scouring the CIE whiteness increased in the course of acid pectinase, alkaline pectinase and alkaline scouring, independent of the temperature of drying. Rigorous alkaline conditions tend to remove waxes, pectins and proteins, as well as colored amino components [1,3]. In mild enzymatic scouring conditions, part of the non-cellulosic as well as colored amino components remained on the cotton surface, giving lower CIE whiteness on enzymatic scoured cotton [6]. All mercerized-scoured yarns dried at $20^{\circ} \mathrm{C}$ have higher CIE whiteness degree than dried at $80^{\circ} \mathrm{C}$. M20SA has $5.1 \%$, M20SB $12.6 \%$ and M20SN $11.5 \%$ higher CIE whiteness degree than the same yarns dried at $80^{\circ} \mathrm{C}$.

Different quantity of the residues of non-cellulosic components gave different color of cotton (Table 4). According to the temperature of drying mercerized yarns are less yellow, have lower $\mathrm{L}^{*}, \mathrm{C}^{*}$ and $\mathrm{H}^{*}$ values and have visual color differences compared to raw cotton ( $\Delta \mathrm{E}$ higher than 1$)$. $\Delta \mathrm{E}^{*}$ of $\mathrm{M} 20 / \mathrm{R}$ is 3.67 and $\Delta \mathrm{E}^{*} \mathrm{M} 80 / \mathrm{R}$ is 3.59 . Alkaline scoured yarns, as a result of almost completely removed noncellulosic components, independently of temperature of drying, have less red and less yellow color comparing with enzymatic scoured. Acid pectinase scoured yarns have lower $\mathrm{L}^{*}$, higher $\mathrm{a}^{*}$ and $\mathrm{b}^{*}$ values than alkaline pectinase and therefore are redder and yellower. Calculated $\Delta \mathrm{E}^{*}$ values between mercerized-scoured and raw yarn showed that color differences are higher on alkaline, followed by alkaline pectinase and acid pectinase scoured, independent of temperature of drying. Last column in Table $\mathbf{4}$ showed that $\Delta \mathrm{E}^{*}$ values on yarns dried at 80 compared to dried at $20^{\circ} \mathrm{C}$ are lower than 1 , and indicated no visual color differences.

\subsection{XPS and Dyeing of the Non-Cellulosic Properties}

The results discussed above indicated that mercerization, temperature of drying after mercerization and different way of scouring applied to mercerized yarns gave different CIE whiteness degree and different color to the treated samples. XPS and staining of different components of non-cellulosic substances of fibers with appropriate dyes are the methods for determination, the composition and the structure of the cuticle $[12,32,33,38-41]$.

The only atoms analyzable by XPS in pure cellulose fiber are carbon and oxygen, since hydrogen cannot be detected due to technique limitations. Low-resolution XPS scans were used to determine the percentages of the elements present on the cotton fiber surface. The analysis of oxygen, carbon and their ratio $(\mathrm{O} / \mathrm{C})$ was especially important for chemical composition determination. The $\mathrm{O} / \mathrm{C}$ ratio for pure cellulose is 0.83 and all lower values indicated the presence of noncellulosic substances on the cotton fiber surface [38]. The $\mathrm{O} / \mathrm{C}$ ratio for raw cotton yarns 0.168 was slightly increased on M80 and slightly decreased on M20 (Table 5). After scouring, the $\mathrm{O} / \mathrm{C}$ ratio on mercerized yarns was significantly increased, independently of temperature of drying after mercerization. The highest value has alkaline scoured, followed by alkaline pectinase and acid pectinase scoured yarns. Temperature of drying has influence on the $\mathrm{O} / \mathrm{C}$ ratio of mercerized-scoured yarns too. Mercerized-differently scoured yarns dried at $80^{\circ} \mathrm{C}$ have from 3.63 to $5.92 \%$ lower $\mathrm{O} / \mathrm{C}$ ratio values than the same yarns dried at $20^{\circ} \mathrm{C}$, depending of the way of scouring. Comparing mercerizedscoured with mercerized yarn, M20SA has $197 \%$, M20SB $152 \%$ and M20SN $75 \%$ higher $\mathrm{O} / \mathrm{C}$ ratio than M20 yarns. On the other hand, M80SA has $165 \%$, M80SB $127 \%$ and M80SN 54\% higher O/C ratio than M80 yarns. It means that the temperature of drying after mercerizing influences the scouring efficiency and quantity of remained non-cellulosic

Table 4. CIE Whiteness, $L^{*}, a^{*}, b^{*}, C^{*}, H^{*}$ and Color Differences $\Delta E^{*}$ on Raw, Mercerized and Mercerized-Differently Scoured Yarns Dried at 20 and $80^{\circ} \mathrm{C}$

\begin{tabular}{|c|c|c|c|c|c|c|c|c|c|}
\hline Samples & $\begin{array}{c}\text { CIE } \\
\text { Whiteness }\end{array}$ & $\mathbf{L}^{*}$ & $\mathbf{a}^{*}$ & $\mathbf{b}^{*}$ & $\mathbf{C}^{*}$ & $\mathbf{H}^{*}$ & $\begin{array}{c}\Delta \mathbf{E}^{*} \\
\text { (treated/ } \\
\text { raw) }\end{array}$ & $\begin{array}{c}\Delta \mathbf{E}^{*} \\
\text { (Mercerized-scoured/ } \\
\text { mercerized) }\end{array}$ & $\begin{array}{c}\Delta \mathrm{E}^{*} \\
\text { (dried at } 80^{\circ} \mathrm{C} / \\
\text { dried at } 20^{\circ} \mathrm{C} \text { ) }\end{array}$ \\
\hline M20 & 22.7 & 85.53 & 1.60 & 8.98 & 9.12 & 79.90 & 3.67 & & \\
\hline M20SA & 51.6 & 90.38 & 0.56 & 5.41 & 5.44 & 84.12 & 7.42 & 6.11 & \\
\hline M20SN & 31.0 & 87.19 & 1.21 & 8.11 & 8.20 & 81.49 & 4.05 & 1.91 & \\
\hline M80 & 21.8 & 85.45 & 1.74 & 9.12 & 9.28 & 79.20 & 3.59 & & 0.21 \\
\hline M80SA & 49.1 & 90.54 & 0.69 & 6.01 & 6.05 & 83.45 & 6.93 & 5.96 & 0.63 \\
\hline
\end{tabular}


components: higher temperature of drying after mercerizing $\left(80^{\circ} \mathrm{C}\right)$, lower scouring efficiency and higher quantity of remained non-cellulosic components after scouring. In our opinion after mercerizing and drying at $80^{\circ} \mathrm{C}$ some part of residual waxes are melted and cover the surface of the fiber with film of wax, disabling the good scouring efficiency.

High-resolution spectra of $\mathrm{C} 1 \mathrm{~s}$ atoms are collected to determine the types and amounts of carbon-oxygen bonds, which is very important for quantitative analysis of cellulose and non-cellulosic substances. A detailed analysis of the oxygen $(\mathrm{O} 1 \mathrm{~s})$ peak is generally less useful. The chemical shifts of carbon $(\mathrm{C} 1 \mathrm{~s})$ in cotton fibers are deconvoluted into four sub-peaks classified into four categories [38, 40]: C1, (unoxidised carbon $\mathrm{C}-\mathrm{C}$ characteristic for waxes), $\mathrm{C} 2$ (carbon with one oxygen bond $\mathrm{C}-\mathrm{O}$ ), $\mathrm{C} 3$ (carbon with two oxygen bonds $\mathrm{C}-\mathrm{O}-\mathrm{C}$ or $\mathrm{C}=\mathrm{O}$, both characteristic for cellulose), and $\mathrm{C} 4$ (carbon with three oxygen bonds $\mathrm{O}=\mathrm{C}-\mathrm{O}$, characteristic for pectin).

Raw cotton fiber, in the analyzed depth till $3 \mathrm{~nm}$, has 93.5 at. $\%$ at $\mathrm{C} 1,3$ at. $\%$ at $\mathrm{C} 2,3$ at. $\%$ at $\mathrm{C} 3$, and 0.5 at.\% at $\mathrm{C} 4$ (Table 5). Although the $\mathrm{O} / \mathrm{C}$ ratio is not significantly changed during mercerizing, the sub-peaks showed significant changes compared to raw cotton yarn. It was found 10.3 and $13.1 \%$ decrease of $\mathrm{C} 1,170$ and $280 \%$ increase of $\mathrm{C} 2$, 83.3 and $113.3 \%$ increase of C3, 400 and $100 \%$ increase of C4 sub-peak, for mercerized yarns dried at 20 and $80^{\circ} \mathrm{C}$, respectively, compared with raw cotton yarn. These results confirmed previous opinion about CIE whiteness that mercerization changed cotton surface.

The temperature of drying after mercerizing has influence on the intensity of sub-peaks too. $\mathrm{C} 1$ and $\mathrm{C} 4$ on mercerized yarns dried at $80^{\circ} \mathrm{C}$ have 3.2 and $60 \%$ lower values, while $\mathrm{C} 2$ and $\mathrm{C} 340.7$ and $16.4 \%$ higher values than dried at $20^{\circ} \mathrm{C}$. C4 sub-peak, that indicated the presence of pectin, suggests that pectin is present in lower quantity on M80 than on M20. It may be either as a result of changes in the structure on cuticle, or as a result of the removal of pectin during drying at higher temperature. We think that the removal of pectin during drying at $80^{\circ} \mathrm{C}$ does not occur.
After mercerizing and drying at $80^{\circ} \mathrm{C}$ part of the residual waxes melt and cover the surface of the fiber with the film of wax, leaving the pectin below the waxy layer.

The intensity of sub-peaks was additionally changed after scouring of mercerized yarns. The intensity of $\mathrm{C} 1$ peak increased towards alkaline, alkaline pectinase and acid pectinase scoured cotton yarn. In the same direction decreased the intensity of $\mathrm{C} 2$ and $\mathrm{C} 4$ sub-peaks.

Temperature of drying after mercerizing influences on the scouring efficiency. In the most cases, $\mathrm{C} 1$ and $\mathrm{C} 4$ have higher, while $\mathrm{C} 2$ has lower values on mercerized-scoured yarns dried at $20^{\circ} \mathrm{C}$ than dried at $80^{\circ} \mathrm{C}$.

Temperature of drying has influence on the hydrophilic properties and surface free energy but this influence is not significant.

Comparing $\mathrm{C} 1$ peak, for characterization of waxes, of mercerized-scoured with mercerized yarns, M20SA has 40.9\%, M20SB 26.2\% and M20SN $13.6 \%$ lower values than M20. On the other hand M80SA has 37.7\%, M80SB 25.9\% and M80SA $8.13 \%$ lower values than M80. The decrease of C1 after scouring is higher on M20 than M80 but the changes have not significant influence.

Scouring of mercerized yarns increased the $\mathrm{C} 4$ peak. The highest increase of $\mathrm{C} 4$ was noticed on mercerized-alkaline, followed by mercerized-alkaline pectinase and mercerizedacid pectinase scoured yarns. During scouring, the outer waxy layer is partly removed. The most rigorous alkaline scouring conditions ( $\mathrm{pH} 12$ at boiling temperature) removed the highest part of waxy layer and the rest of pectin (which is located mostly under waxy layer) remained on the surface. Although the pectinase act on pectin they could not remove all pectin that is under the waxy surface layer. After enzymatic scouring the removed part of waxy layer is lower compared to alkaline scouring. Waxes remain in higher quantity on the top of the fiber surface, and therefore the $\mathrm{C} 4$ on MSB and MSN are lower than on MSA.

The non-cellulosic components can be determined by staining with appropriate dyes. Using this technique, the

Table 5. XPS Analysis on Raw, Mercerized and Mercerized-Differently Scoured Yarns Dried at 20 and $80^{\circ} \mathrm{C}$

\begin{tabular}{|c|c|c|c|c|c|c|c|}
\hline \multirow{3}{*}{ Samples } & \multirow{3}{*}{ C1s } & \multirow{3}{*}{ 01s } & \multirow{3}{*}{$\mathrm{O} / \mathrm{C}$} & \multicolumn{4}{|c|}{ Binding Energy } \\
\hline & & & & $\begin{array}{c}\mathrm{C}-\mathrm{C} \\
(285.0 \mathrm{eV})\end{array}$ & $\begin{array}{c}\mathrm{C}-\mathrm{O} \\
(286.6 \mathrm{eV})\end{array}$ & $\begin{array}{c}\text { O-C-O } \\
(288.1 \text { eV })\end{array}$ & $\begin{array}{c}\mathrm{O}-\mathrm{C}=\mathrm{O} \\
(289.4 \mathrm{eV})\end{array}$ \\
\hline & & & & C1 (at. \%) & C2 (at. \%) & C3 (at. \%) & C4 (at. \%) \\
\hline $\mathrm{R}$ & 84.25 & 14.20 & 0.168 & 93.5 & 3.0 & 3.0 & 0.5 \\
\hline M20 & 83.90 & 13.80 & 0.164 & 83.9 & 8.1 & 5.5 & 2.5 \\
\hline M20SA & 65.90 & 32.20 & 0.488 & 49.6 & 38.3 & 8.0 & 4.1 \\
\hline M20SB & 68.70 & 28.40 & 0.413 & 61.9 & 28.6 & 6.2 & 3.3 \\
\hline M20SN & 75.30 & 21.60 & 0.287 & 72.5 & 15.9 & 11.0 & 0.6 \\
\hline M80 & 83.15 & 14.60 & 0.175 & 81.2 & 11.4 & 6.4 & 1.0 \\
\hline M80SA & 66.90 & 30.95 & 0.463 & 50.6 & 32.8 & 14.6 & 2.0 \\
\hline M80SB & 69.10 & 27.55 & 0.398 & 60.15 & 25.1 & 12.8 & 1.95 \\
\hline M80SN & 76.53 & 20.60 & 0.270 & 74.6 & 15.5 & 8.6 & 1.3 \\
\hline
\end{tabular}


changes in the structure of cuticle of the cotton fiber can be detected visually. Himmelsbach S. D. and coworkers demonstrated that this method is also suitable for the determination of the structure and composition of seed coat fragments [41]. Canal J. M. and his coworkers studied enzymatic scouring efficiency by dyeing scoured cotton with dyes for noncellulosic components of cotton surface [33].

Table 6. $L^{*}$ Values on Raw, Mercerized and MercerizedDifferently Scoured Yarns Dried at 20 and $80^{\circ} \mathrm{C}$, Dyed with Oil Red $\left(\mathrm{L}^{*}{ }_{\mathrm{OR}}\right)$, Methylene Blue $\left(\mathrm{L}^{*}{ }_{\mathrm{MB}}\right)$ and Bemacid Blau GLF $200 \%\left(L^{*}{ }_{\text {Bв}}\right)$

\begin{tabular}{|c|c|c|c|}
\hline Sample & $\mathbf{L}^{*}{ }_{\mathrm{OR}}$ & $\mathbf{L}^{*}{ }_{\mathrm{MB}}$ & $\mathbf{L}^{{ }_{\text {}}}{ }$ \\
\hline \hline $\mathrm{R}$ & 44.26 & 50.36 & 75.54 \\
\hline M20 & 56.96 & 55.23 & 73.75 \\
\hline M20SA & 62.81 & 68.37 & 77.76 \\
\hline M20SB & 57.14 & 63.94 & 73.12 \\
\hline M20SN & 50.73 & 59.55 & 73.98 \\
\hline M80 & 54.36 & 55.09 & 75.93 \\
\hline M80SA & 61.28 & 67.22 & 78.74 \\
\hline M80SB & 55.21 & 60.40 & 74.15 \\
\hline M80SN & 50.23 & 57.17 & 74.74 \\
\hline
\end{tabular}

Differently treated yarns were dyed with oil red (OR) to determine the waxes, methylene blue (MB) for pectins, and bemacid blue $(\mathrm{BB})$ for proteins. The measured $\mathrm{L}^{*}$ values are given in Table 6. The $\mathrm{L}^{*}{ }_{\mathrm{OR}}$ and $\mathrm{L}^{*}{ }_{\mathrm{MB}}$ values confirmed previously reported results, and they have high coefficients of correlation between them as well as the CIE whiteness, $\mathrm{O} / \mathrm{C}$ ratio, and $\mathrm{C} 1, \mathrm{C} 2$, and $\mathrm{C} 4$ sub-peaks (Table 7 ). The $\mathrm{L}^{*}{ }_{\mathrm{BB}}$ does not have good coefficients of correlation between other investigated parameters, except with CIE whiteness. Although the raw cotton displayed darker staining than mercerized (lower L* ${ }^{*}$ values), the staining showed more irregularities than on mercerized cotton that was dyed lighter but more evenly. This confirms the previous conclusion that, after mercerizing and especially after drying at higher temperature, a part of the residual waxes melts down to cover the surface of the fiber. (M80 is more evenly dyed with oil red than by M20).

Comparing the $\mathrm{L}^{*}$ oR values of mercerized-differently scoured yarns with only a mercerized cotton an increase is evident on M20SA, M20SB, M80SA and M80SB while a decrease is noticed on M20SN and M80SN. These results suggest a poor scouring efficiency of acid pectinase in acid conditions with a negligible removing of pectins as well as leaving of waxes on the surface of the fiber.

\subsection{Wettability and Surface Free Energy}

The results presented in Table $\mathbf{8}$ showed that all scouring processes increased the wettability of cotton yarns compared with the raw sample. The latter were highly hydrophobic, which prevented DIM, W, and FA from penetration into its porous structure. Mercerization of the raw cotton yarn

Table 7. Coefficients of Correlation between Measured Parameters

\begin{tabular}{|c|c|c|c|c|c|c|c|c|c|c|c|c|c|c|c|c|c|c|}
\hline & CIE W & $\mathbf{L}^{*}$ & $\mathbf{a}^{*}$ & $\mathbf{b}^{*}$ & $\mathrm{C}^{*}$ & $\mathbf{H}^{*}$ & O/C & $\begin{array}{l}\text { C-C } \\
(\mathrm{eV})\end{array}$ & $\begin{array}{l}\text { C-O } \\
(\mathrm{eV})\end{array}$ & $\begin{array}{c}\text { O-C-O } \\
\text { (eV) }\end{array}$ & $\begin{array}{c}\mathrm{O}-\mathrm{C}=\mathrm{O} \\
(\mathrm{eV})\end{array}$ & $\mathbf{L}_{\mathrm{OR}}$ & $\mathbf{L}_{\mathrm{MB}}$ & $\mathbf{L}_{\mathrm{BB}}$ & $\begin{array}{l}\Theta \\
\left({ }^{\circ}\right)\end{array}$ & $\gamma_{\mathrm{s}}^{\mathrm{d}}$ & $\gamma_{\mathrm{s}}^{\mathrm{p}}$ & $\gamma_{s}^{\text {tot }}$ \\
\hline CIE W & 1 & $0.83^{\text {a) }}$ & -0.97 & -0.98 & -0.93 & 0.71 & 0.91 & -0.96 & 0.93 & 0.73 & 0.61 & 0.81 & 0.98 & 0.61 & -0.98 & 0.94 & 0.88 & 0.89 \\
\hline $\mathbf{L}^{*}$ & & 1 & -0.91 & -0.82 & -0.67 & 0.95 & 0.92 & -0.85 & 0.86 & 0.53 & 0.53 & 0.55 & 0.83 & 0.58 & -0.97 & 0.96 & 0.96 & 0.96 \\
\hline $\mathbf{a}^{*}$ & & & 1 & 0.97 & 0.84 & -0.80 & -0.92 & 0.93 & -0.91 & -0.73 & -0.49 & -0.67 & -0.89 & -0.66 & 0.97 & -0.93 & -0.85 & -0.86 \\
\hline $\mathbf{H}^{*}$ & & & & & & 1 & 0.81 & -0.71 & 0.74 & 0.35 & 0.48 & 0.39 & 0.72 & 0.55 & -0.89 & 0.83 & 0.83 & 0.84 \\
\hline $\mathrm{O} / \mathrm{C}$ & & & & & & & 1 & -0.97 & 0.97 & 0.63 & 0.66 & 0.70 & 0.95 & 0.40 & -0.89 & 0.90 & 0.96 & 0.96 \\
\hline $\mathrm{C}-\mathrm{C}(\mathrm{eV})$ & & & & & & & & 1 & -0.98 & -0.70 & -0.67 & -0.81 & -0.97 & -0.44 & 0.95 & -0.94 & -0.98 & -0.98 \\
\hline C-O (eV) & & & & & & & & & 1 & 0.58 & 0.74 & 0.81 & 0.98 & 0.44 & -0.94 & 0.86 & 0.93 & 0.93 \\
\hline $\mathbf{L}_{\mathrm{OR}}$ & & & & & & & & & & & & 1 & 0.84 & 0.43 & -0.91 & 0.91 & 0.94 & 0.94 \\
\hline $\mathbf{L}_{\mathrm{MB}}$ & & & & & & & & & & & & & 1 & 0.44 & -0.86 & 0.85 & 0.85 & 0.86 \\
\hline $\mathbf{L}_{\mathrm{BB}}$ & & & & & & & & & & & & & & 1 & -0.87 & 0.81 & 0.67 & 0.70 \\
\hline$\Theta\left({ }^{\circ}\right)$ & & & & & & & & & & & & & & & 1 & -0.95 & -0.94 & -0.95 \\
\hline$\gamma_{\mathrm{s}}^{\mathrm{d}}$ & & & & & & & & & & & & & & & & 1 & 0.94 & 0.95 \\
\hline$\gamma_{s}^{\mathrm{p}}$ & & & & & & & & & & & & & & & & & 1 & 0.99 \\
\hline$\gamma_{\mathrm{s}}^{\text {tot }}$ & & & & & & & & & & & & & & & & & & 1 \\
\hline
\end{tabular}

The correlation coefficients above 0.6 are given in bold. 
Table 8. Liquid Penetration Rate $\left(x^{2} / t\right)$, Capillary Radius, R, and Contact Angles of Different Liquids into Mercerized-Differently Scoured Cotton Yarns Dried at 20 and $80^{\circ} \mathrm{C}$

\begin{tabular}{|c|c|c|c|c|c|c|c|c|}
\hline \multirow{2}{*}{ Sample } & \multicolumn{4}{|c|}{$x^{2} / t\left(\mathrm{~cm}^{2} \mathrm{~s}^{-1}\right)$} & \multirow{2}{*}{$\mathbf{R}(\mu \mathbf{m})$} & \multicolumn{3}{|c|}{$\theta\left({ }^{\circ}\right)$} \\
\hline & C7 & DIM & $\mathbf{W}$ & FA & & DIM & $\mathbf{W}$ & FA \\
\hline $\mathrm{R}$ & 1.730 & $\rho^{\text {a) }}$ & I & I & 6.96 & - b) & - & - \\
\hline M20SA & 2.095 & 0.092 & 0.521 & 0.430 & 8.42 & 83.08 & 80.21 & 36.73 \\
\hline M20SB & 2.069 & 0.055 & 0.277 & 0.357 & 8.32 & 85.80 & 84.74 & 47.66 \\
\hline M80 & 1.875 & I & I & I & 7.54 & - & - & - \\
\hline M80SA & 1.883 & 0.063 & 0.449 & 0.374 & 7.57 & 84.7 & 80.61 & 39.2 \\
\hline M80SB & 1.914 & 0.043 & 0.102 & 0.264 & 7.69 & 86.4 & 87.90 & 57.3 \\
\hline M80SN & 1.935 & 0.021 & 0.025 & 0.032 & 7.78 & 88.3 & 89.49 & 86.3 \\
\hline
\end{tabular}

a) Liquid depression.

${ }^{b)}$ Calculation could not be made.

(samples M20 and M80) did not significantly change its wettability. Although the non-cellulosic components were partly removed from the cotton surface during the mercerization, this process alone did not improve wettability of the cotton. For this reasons, scouring of the cotton should be carried out. The results in Table $\mathbf{8}$ also showed that the water contact angle of mercerized differently scoured yarns decreased in direction acid pectinase, alkaline pectinase and alkaline scoured yarns, independent of the temperature of drying. Alkaline scoured sample was more hydrophilic than the alkaline pectinase and acid pectinase scoured samples. These results were in agreement with the results of the CIE whiteness, CIELAB coordinates, $\mathrm{O} / \mathrm{C}$ ratio, and $\mathrm{C} 1, \mathrm{C} 2$, and $\mathrm{C} 4$ sub-peaks and have high correlation coefficients between them. Although the wettability of mercerized-scoured yarns are higher than mercerized, mercerized-acid pectinase scoured yarns have the lowest wettability, independent of the temperature of drying. Our previous investigations conc- luded that acid pectinase scouring gave good wettability to raw fabrics, similar to scouring with alkaline pectinase [22]. The temperature of drying after mercerizing also influences the wettability after scouring. Yarns dried at $20^{\circ} \mathrm{C}$ have higher wettability than dried at $80^{\circ} \mathrm{C}$. Acid pectinase scoured yarns previously dried at $80^{\circ} \mathrm{C}$ have the lowest wettability. After mercerizing and drying at $80^{\circ} \mathrm{C}$, part of the residual waxes melt down, covering the surface of the fiber similar to the covering of the surface of the cotton after the extraction of waxes by organic solutions [42]. The changes in the cotton surface prevented the penetration of acid pectinases into it (in acid media) enabling the digesting of pectin. This resulted in poor scouring efficiency. The temperature of drying after mercerizing influences the apparent capillary radius of the yarns that decreases as the temperature of drying is increased (Table 8 ).

Results presented in Table 9 also revealed that the manner of the pretreatment process influenced the surface

Table 9. Values of Surface Free Energy, $\gamma_{s}^{\text {tot }}$, its Disperse, $\gamma_{s}^{d}$, and Polar, $\gamma_{s}^{p}$, Components on Mercerized-Differently Scoured Cotton Yarns Dried at 20 and $80^{\circ} \mathrm{C}$

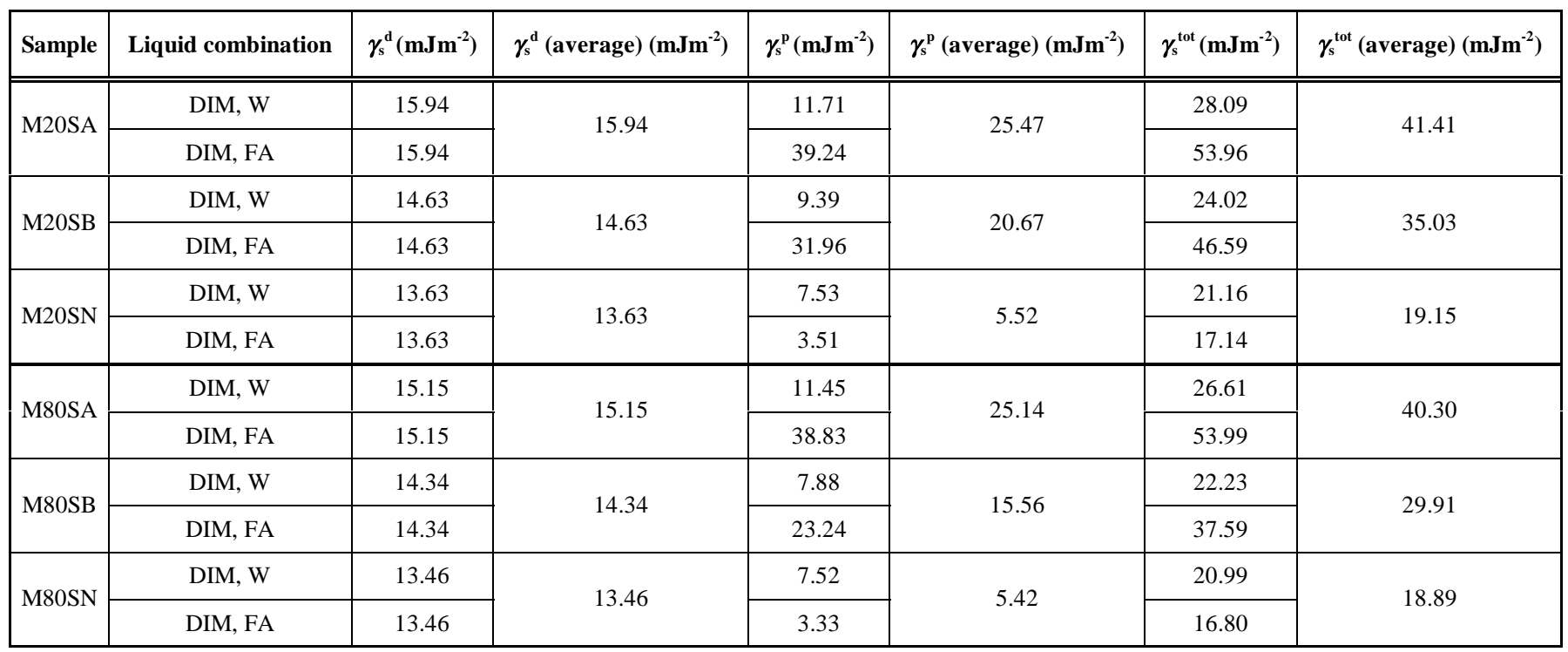


Table 10. Evaluated Fisher (F) Test Values and p-Values for Significance on Way Scouring (Variable A, $F_{A}$ ) and Temperature on Drying after Mercerizing, (Variable $B, F_{B}$ ) on all Investigated Properties

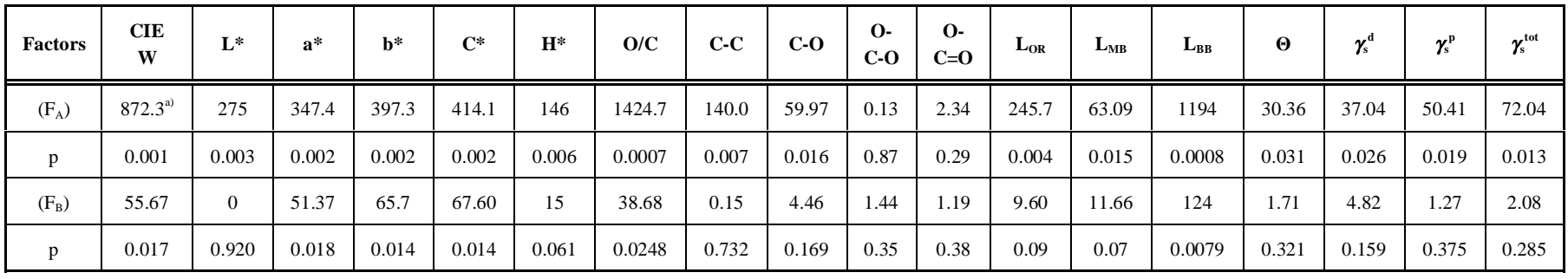

a) The evaluated $\mathrm{F}$ values as well as p-values given in a bold indicated significant influence on the factor $\mathrm{A}$ and $\mathrm{B}$ on the measured properties.

free energy of the cotton fibers. As expected, the value of the polar component, $\gamma_{S}^{p}$, was additionally affected by the liquid combination [43]. Irrespective of this, the $\gamma_{s}^{\text {tot }}$ values increased as following: mercerized-acid pectinase, mercerizedalkaline pectinase and mercerized-alkaline scoured yarn, independent of temperature of drying. These results correlate with the hydrophilicity of the yarns, (coefficient of correlation $\gamma_{S}^{\text {tot }}-\theta$ is -0.95). While the dispersive components, $\gamma_{S}^{d}$

(which fell in the range from 13.46 to 15.94 ) seemed to be slightly affected by the pretreatment process, the polar components, $\gamma_{S}^{p}$, significantly changed with the treatment conditions (Table 9). Higher efficiency of the process gives higher polarity of the surface. This is reasonable, since the removal of the non-cellulosic components during the scouring processes results in an increase of the polar hydroxyl groups on the cotton surface.

\subsection{Analysis of Variance}

The influence of the ways of scouring (variable A) and the temperature of drying after mercerizing (variable B) on the properties of the yarns were analyzed by the main effects analysis of variance (ANOVA). The results are given in Table $\mathbf{1 0}$ as evaluated Fisher F-test values, and p-values (variables have significant influence on the measured properties where $\mathrm{p}<0.05)$ for investigated parameters. The way of scouring has a significant influence on the CIE whiteness degree, CIELAB coordinates $\mathrm{L}^{*}, \mathrm{a}^{*}, \mathrm{~b}^{*}, \mathrm{C}^{*}, \mathrm{H}^{*}$, $\mathrm{L}^{*}{ }_{\mathrm{OR}}, \mathrm{L}{ }_{\mathrm{MB}}, \mathrm{L}{ }_{\mathrm{BB}}, \mathrm{O} / \mathrm{C}, \mathrm{C} 1, \mathrm{C} 2, \Theta, \gamma_{\mathrm{s}}^{\mathrm{d}}, \gamma_{\mathrm{s}}^{\mathrm{p}}, \gamma_{\mathrm{s}}^{\text {tot }}$.

The temperature of drying after mercerizing has significant influence on the CIE whiteness degree, CIELAB coordinates $\mathrm{a}^{*}, \mathrm{~b}^{*}, \mathrm{C}^{*}, \mathrm{~L}^{*}{ }_{\mathrm{BB}}$ and $\mathrm{O} / \mathrm{C}$.

\section{CONCLUSIONS}

- Mercerizing and temperature of drying after mercerizing have influence on the non-cellulosic components in the cuticle, and have influence on the enzymatic scouring efficiency.

- Mercerizing changes the surface of the cotton fibers, removing part of the cuticle, decreasing the waxy layer, and after drying at $80^{\circ} \mathrm{C}$ turning it into a continuous thin layer that enhances the alkaline and alkaline pectinase scouring and enables acid pectinase scouring.
- Mercerized-differently scoured yarns dried at $80^{\circ} \mathrm{C}$ have lower capillary radius than dried at $20^{\circ} \mathrm{C}$.

- Temperature of drying has influence on the hydrophilic properties and surface free energy but this influence is not significant. The way of scouring significantly changes surface free energy, its disperse and polar components.

- Way of scouring has a significant influence on almost all measured properties, but the temperature of drying has influence on parameter, such as CIE whiteness, CIELAB coordinates $\mathrm{L}^{*}, \mathrm{a}^{*}, \mathrm{~b}^{*}, \mathrm{~L}^{*}{ }_{\mathrm{BB}}$ and $\mathrm{O} / \mathrm{C}$.

\section{ACKNOWLEDGEMENT}

The Authors gratefully acknowledge the financial support of the Ministry of Education and Science of the Republic of Macedonia for supporting the project No. 13814/3-05.

\section{REFERENCES}

[1] S. W. Perkin, Textile Coloration and Finishing, Caroline Academic Press: Durham, North Carolina, U.S.A., 1996.

[2] Y. Matoba, Lectures on Mercerization, Available online on http://textileinfo.com, 01/05/2004.

[3] G. Buschle-Diller, Y. El Mogahzy, M. K. Inglesby, and S. H Zeronian, "Effects of scouring with enzymes, organic solvents, and caustic soda on the properties of hydrogen peroxide bleached cotton yarn", Textile Res. J., vol. 68, No. 12, pp. 920-929, December, 1998.

[4] Y. Li, and I. R. Hardin, "Treating cotton with cellulases and pectinases: effect on cuticle and fiber properties", Textile Res. J., vol. 68, No. 9, pp. 671-679, September 1998.

[5] Y. Li, and I. R. Hardin, "Enzymatic scouring of cotton-surfactants, agitation, and selection of enzymes", Textile Chem. Color., vol. 30, No. 9, pp. 23-29, September 1998.

[6] Y. Li, and I. R. Hardin, "Enzymatic scouring of cotton: effects on structure and properties", Textile Chem. Color., Vol. 29, No. 8, pp. 71-76, August 1997.

[7] M.M. Hartzell, and Y. L. Hsieh, "Enzymatic scouring to improve cotton fabric wettability", Textile Res. J., Vol. 68, No. 4, pp. 233241, April 1998.

[8] E. Csiszár, G. Szakács, and I. Rusznák, "Combining traditional cotton scouring with cellulase enzymatic treatment", Textile Res. J., vol. 68, No. 3, pp. 163-167, March 1998.

[9] E. Csiszár, G. Szakács, and I. Rusznák, "Enzyme applications in fiber processing, ACS Symposium Series \#687, K. E. L. Ericsson, and A. Cavaco-Paulo, Eds, American Chemical Society, Washington DC, USA, 1998, pp. 204-211,

[10] E. Csiszár, K. Urbánszki and G. Szakács, "Biotreatment of desized cotton fabric by commercial cellulase and xylanase enzymes", $J$. Mol. Catal. B. Enzyme, vol. 11, No. 4-6, pp. 1065-1072, January 2001. 
[11] K. Sawada, S. Tokino, M. Ueda, and Y. W. Wang, "Bioscouring of cotton with pectinase enzyme", J. Soc. Dyers Color., vol. 114, No. 11, pp. 333-336, November 1998.

[12] J. Buchert, J. Pere, A. Puolakka, and P. Nousiainen, "Scouring of cotton with pectinases, proteases, and lipases", Textile Chem. Color. Am. Dyest. Rep., vol. 32, No. 5, pp. 48-52, May 2000.

[13] M. K. Traore, and G. Buschle-Diller, "Environmentally friendly scouring processes", Textile Chem. Color./Am. Dyest. Rep., vol. 32, No. 12, pp. 40-43, December 2000.

[14] U. Sangwatanaroj, K. Choonukulpong, and M. Ueda, "Cotton scouring with pectinase and lipase/protease/cellulase”, AATCC Rev., vol. 3, No. 5, pp. 17-20, May 2003.

[15] E. Karapinar, and M. O. Sariisik, "Scouring of cotton with cellulases, pectinases and proteases", Fibers Text. East Eur., vol. 12, No. 3, pp. 79-82, July/October 2004.

[16] M. Calafell, and P. Garriga, "Effect of some process parameters in the enzymatic scouring of cotton using an acid pectinase", Enzyme Microb. Technol., vol. 34, No. 3-4, pp. 326-331, March 2004.

[17] P. F. Tavcer, and P. Presa, "Pretreatment of cotton with pectinases and peracetic acid", Tekstil, vol. 53, No. 3, pp. 110-118, March 2004.

[18] P. Presa, and P. F. Tavcer, "Bioscouring and bleaching of cotton with pectinase enzyme and peracetic acid in one bath", Color. Technol., vol. 124, No. 1, pp. 36-42, February 2008.

[19] P. F. Tavcer, "The Influence of different pretreatments on the quantity of seed-coat fragments in cotton fibres", Fibers Text. East Eur., vol. 16, No. 1 (66), pp. 19-23, January/March 2008.

[20] J. N. Etters, "Cotton preparation with alkaline pectinase: an environmental advance", Textile Chem. Color. Am. Dyest. Rep., vol. 1, No. 3, pp. 33-36, November 1999.

[21] I. Jordanov, and B. Mangovska, "Optimal parameters of enzymatic scouring and compared with alkaline scouring”, Tekstil, vol. 50, No. 10, pp. 501-508, October 2001.

[22] I. Jordanov, and B. Mangovska, "Enzymatic scouring of cotton knitted fabrics with acid pectinase, cellulase and lacase", Vlakna a Textile, vol. 14, No. 3-4, pp. 28-40, 2007.

[23] I. Jordanov, and B. Mangovska, "Enzymatic and alkaline scouring on cotton yarns and characterization of knitted goods made of them", Tekstil, vol. 52, No. 3, pp. 104-110, March 2003.

[24] B. Mangovska, G. Demboski, and I. Jordanov, "Structural characterization of cotton knitted fabrics after enzymatic and alkaline scouring", Bull. Chem. Technol. Macedonia, vol. 23, pp. 19-28, 2004.

[25] I. Jordanov, and B. Mangovska, "Enzymatic scouring of terry for towels", Vlakna a Textile, vol. 11, No. 2, pp. 43-49, 2004.

[26] B. Mangovska, and I. Jordanov, "Pad roll bioscouring process for cotton woven fabrics", AATCC Rev., vol. 6, No. 3, pp. 33-36, March 2006.

[27] I. Jordanov, B. Mangovska, and P. F. Tavcer "Assessing structural changes in cotton yarns during wet processing, mercerization, and scouring”, AATCC Rev., vol. 7, No. 8, pp. 56-61, August 2007.
[28] G. R. Gamble, "Effect of elevated temperatures on the chemical properties of cotton fiber pectin", Textile Res. J., vol. 73, No. 2, pp. 157-160, February 2003

[29] L. E. Hessler, and H. Workman, "Heat induced chemical changes cotton fiber", Textile Res. J., vol. 29, No. 6, pp. 487-492, June 1959.

[30] F. H. Coward, and L. Spencer, "The absorption of caustic soda solution by cotton" J. Textile Inst., vol. 14, No. 1, pp. 32-45, 1923.

[31] M. K. Inglesby, and S. H. Zeronian, "The accessibility of cellulose as determined by dye adsorption", Cellulose, vol. 3, pp. 165-181, 1996.

[32] D. E. Akin, L. L. Rigsby, and H. W. Morrison, III, "Oil red as a histochemical stain for natural fibers and plant cuticle", Indust. Crops Products, vol. 19, No. 2, pp. 119-124, March 2004.

[33] J. M. Canal, A. Navarro, M. Calafell, C. Rodriguez, G. Caballero, B. Vega, C. Canal, and R. Paul, "Effect of various bioscouring systems on the accessibility of dyes into cotton", Color. Technol., vol. 120, No. 6, pp. 311-315, November 2004.

[34] C. J. Van Oss, R. F. Giese, Z. Li, K. Murphy, J. Norris, M. K. Chaudhury, and R. J. Good, "Determination of contact angles and pore size of porous media by column and thin layer wicking”, $J$. Adhesion Sci. Technol., vol. 6, No. 4, pp. 413-428, April 1992.

[35] K. D. Owens, and R. C. Wendt, "Estimation of the surface free energy of polymers", J. Appl. Polym. Sci., vol. 13, No. 8, pp. 17411747, August 1969.

[36] H. D. Kaelble, "Dispersion-polar surface tension properties of organic solids", J. Adhesion, vol. 2, No. 2, pp. 66-81, 1970.

[37] C. Chatfield, Statistics for Technology, Penguin Books Ltd, Harmondsworth, Middlesex, England, First Published 1970, pp. 155-185.

[38] T. Topalovic, V. A. Nierstrasz, L. Bautista, D. Jocic, A. Navarro, and M. M. C. G. Warmoeskerken, "XPS and contact angle study of cotton surface oxidation by catalytic bleaching", Colloids Surf. A: Physicochem. Eng. Aspects, vol. 296, No. 1-3, pp. 76-85, 15 March 2007.

[39] J. Buchert, J. Pere, L. -S. Johansson, and J. M. Campbell, "Analysis of the surface chemistry of linen and cotton fabrics", Textile Res. J., vol. 71, No. 7, pp. 626-629, July 2001.

[40] R. Mitchell, C. M. Carr, M. Parfitt, J. C. Vickerman, and C. Jones, "Surface chemical analysis of raw cotton fibers and associated materials", Cellulose, vol. 12, pp. 629-639, 2005.

[41] D. S. Himmelsbach, D. E. Akin, J. Kim, and I. R. Hardin, "Chemical structural investigation of the cotton fiber base and associated seed coat: fourier-transform infrared mapping and histochemistry", Textile Res. J., vol. 73, No. 4, pp. 281-288, April 2003.

[42] N. B. Melnikov, B. I. Bliniceva, I. G. Vinogradova, and I. V. Lebedeva, Progress in Textile Chemistry, Legprombitizdat; Moscow, 1988, pp. 17-18.

[43] L. Černe, B. Simončič, and M. Željko, "The influence of repellent coatings on surface free energy of glass plate and cotton fabrics", Appl. Surf. Sci., vol. 254, No. 20, pp. 6467-6477, August 2008.

(C) Jordanov and Mangovska; Licensee Bentham Open.

This is an open access article licensed under the terms of the Creative Commons Attribution Non-Commercial License (http://creativecommons.org/licenses/by$\mathrm{nc} / 3.0 /$ ), which permits unrestricted, non-commercial use, distribution and reproduction in any medium, provided the work is properly cited. 